Proc. Indian Acad. Sci. (Earth Planet. Sci.), Vol. 95, No. 3, November 1986, pp. 363-371.

(C) Printed in India.

\title{
Lineament analysis of Cannanore district and their implication on the tectonic evolution of the area
}

\author{
VENKATESH RAGHAVAN and NARAYANASWAMY \\ Centre for Earth Science Studies, P. B. 2235, Sasthamangalam, \\ Trivandrum 695010 , India \\ MS 7 August 1984; revised 18 April 1986
}

\begin{abstract}
The Cannanore district and the adjoining areas mainly comprise of charnokites, gniesses, high and low-grade schists and various types of igneous intrusives. The lineament fabric of the region indicates that the NNW-SSE, NW-SE, ENE-WSW and $\mathrm{NE}-\mathrm{SW}$ lineament directions are prominent. It is suggested that the area has undergone at least three distinct phases of tectonic activity. The NW-SE and ENE-WSW lineaments appear to have formed during the phase of NW-SE folding. The NE-SW lineaments may be the result of the cross-folding of the earlier folds. The NNW-SSE lineaments have been related to the Precambrian tectonic activity in South India.
\end{abstract}

Keywords. Lineament analysis; tectonic evolution; tensional fractures; basic magmatism; reactivation.

\section{Introduction}

Although lineaments are known to provide significant information on the tectonic evolution of a region, systematic study of linements in the Kerala region is very limited. Eremenko (1968) identified NW-SE, WNW-ESE, NNW-SSE, N-S and NE-SW lineaments in Kerala. Vardarajan and Nair (1978) and Katz (1982) made a broad study of lineaments in Kerala. Drury and Holt (1980) and Drury et al (1984) summarized remote sensing, geological, geochemical and geophysical data and brought out a detailed tectonic interpretation of the South Indian shield. These studies indicate that despite the masking of bed rock by extensive cover of laterites, Quaternary deposits and vegetation, major structures can generally be deciphered.

In the study area three mega-lineaments namely $\mathrm{N} 36^{\circ} \mathrm{W}-\mathrm{S} 36^{\circ} \mathrm{E}$ (through Kuthuparamba), $\mathrm{N} 40^{\circ} \mathrm{W}-\mathrm{S} 40^{\circ} \mathrm{E}$ (through Manantoddy) and $\mathrm{N} 80^{\circ} \mathrm{W}-\mathrm{S} 80^{\circ} \mathrm{E}$ (through Mogral) have been reported (Nair et al 1975). The lineament fabric in Kerala was hitherto partly related to the distensional tectonics in response to the rifting of the western continental margin of India (eg. Eremenko 1968; Vardarajan and Nair 1978; Rao 1978; Sinha Roy and Furnes 1981; Furnes et al 1983). Here we report new lineament analysis data from North Kerala and suggest that the lineament fabric in the region has developed as a result of Precambrian deformational events.

\section{Geology}

Figure 1 shows the disposition of various geological units in the area. The area is principally composed of charnokites, gneisses, high- and low-grade schistose rocks. 


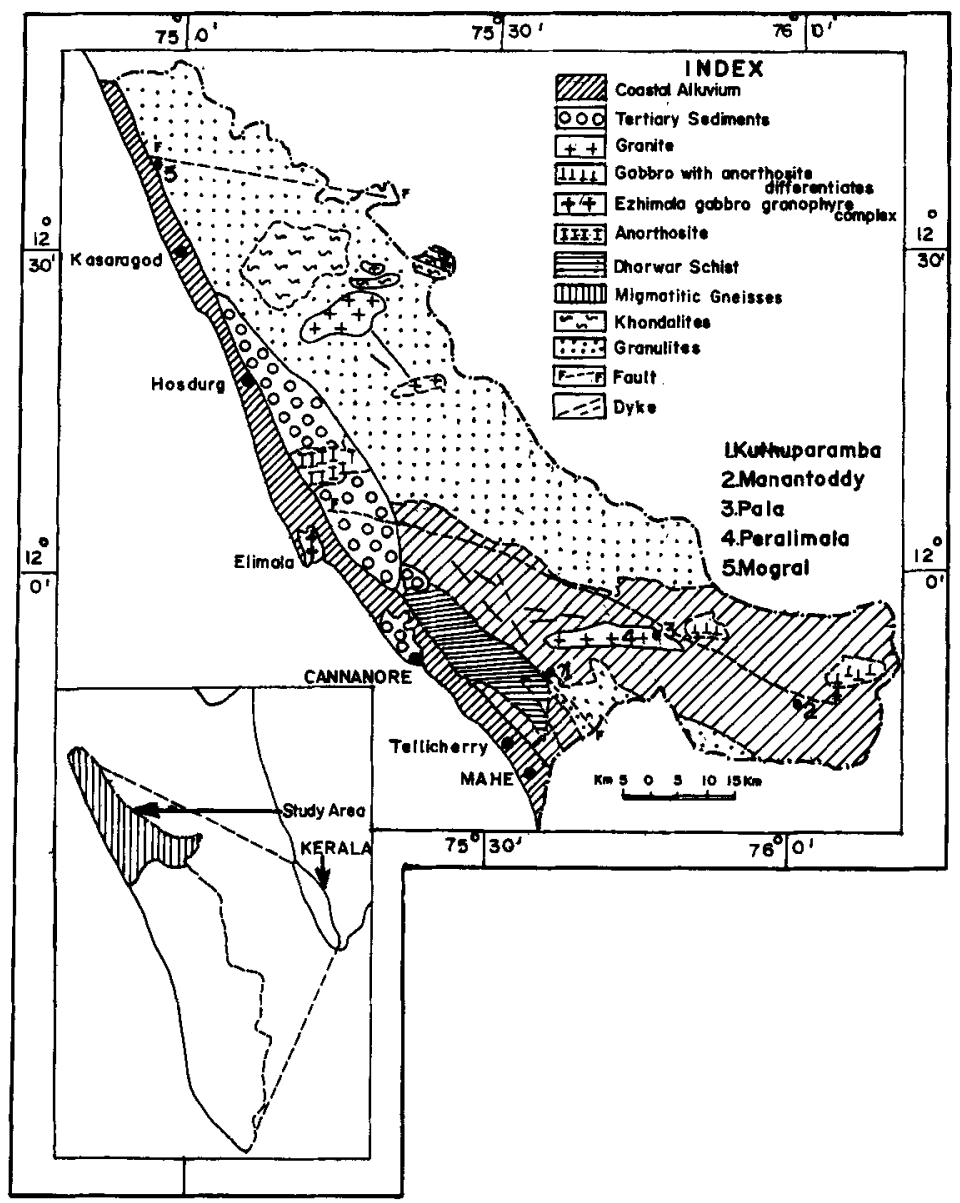

Fïgure 1. A generalized geological map of Cannanore district (compiled from various sources).

Gabbro, anorthosite, granophyre, granite and syenite occur as intrusive phases. In addition, numerous doleritc dykes trending in the NNW-SSE and ENE-WSW directions cut across all the lithounits. North of Pala, blocks of basic dyke occur as enclaves within the Peralimala granite (figure 2) which has yielded a $\mathrm{Rb}-\mathrm{Sr}$ isochron age of $760 \pm 70 \mathrm{~m} . \mathrm{y}$. (Santosh, personal communication). The coastal belt comprises of a narrow discontinuous NNW-SSE trending belt of tertiary sediments and recent alluvial deposits.

The Cannanore region has undergone several episodes of deformation as that of the Precambrian terrane of Kerala (Nair 1975; Murthy et al 1976; Rao 1978; Nair and Nair 1980). Isoclinal folds with axial surface trending E-W to ENE-WSW represent the early phase of deformation. The second phase of deformation has resulted in folds with NNW-SSE to NW-SW axial surface. Folds with NE-SW to NNE-SSW axial plane probably represent the last phase of deformation (Nair et al 1980). 


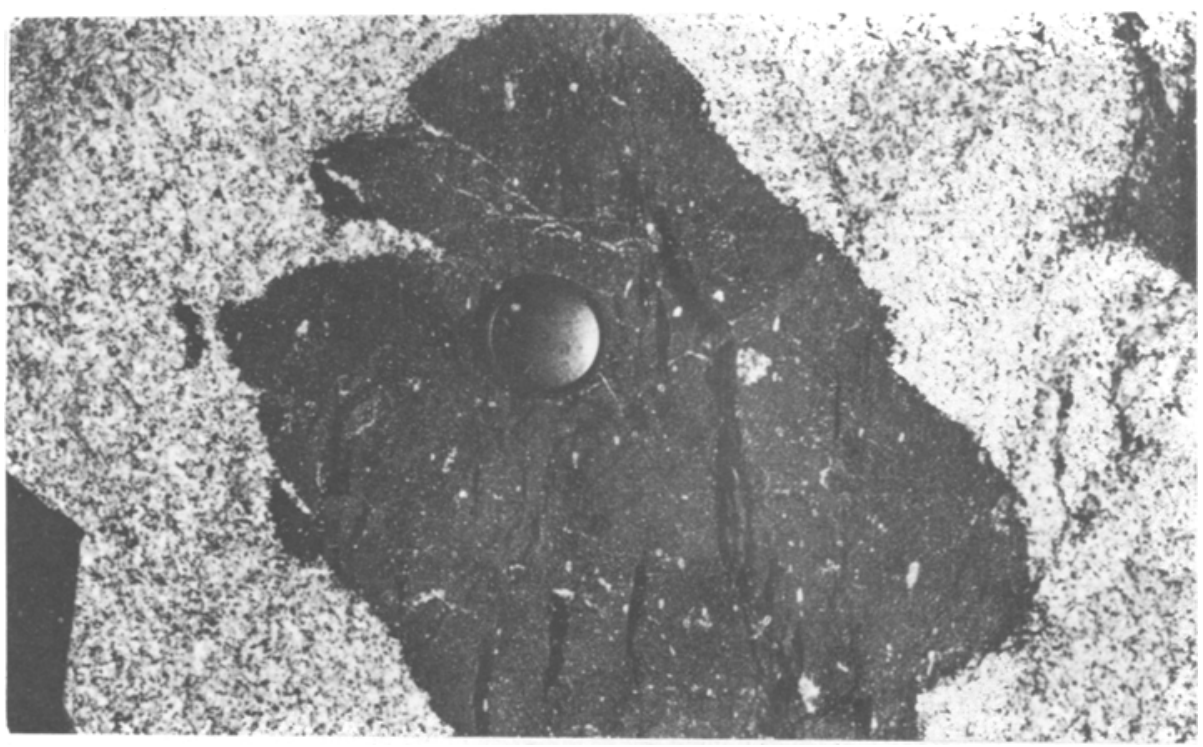

Figure 2. Doleritic enclaves in granite (Pala, Cannanore district).

\section{Lineament analysis}

Landsat images of 12,50,000 scale (Band 5, 7 and false colour composites) were studied using visual interpretation techniques. The lineaments identified using the above technique were transferred on to topographic maps using a Carl Zeiss Sketchmaster and cultural features were filtered out as far as possible. The lineament map of the area is given in figure 3. Limited field checks were carried out to verify the lineaments. The lineaments observed in the area are mainly due to incised fractures/shears of varying dimensions, dykes, differential erosion and vegetation. The highland regions in Cannanore district exhibit lineament pattern more clearly and towards the lowland regions the lineament density decreases due to various obscuring factors which include extensive soil and laterite cover, vegetation and cultivated land.

The orientation and length of lineaments were recorded and lineaments were grouped into 18 azimuth classes of $10^{\circ}$ interval. Table 1 gives the mean azimuth, mean observable length and standard deviation for each azimuth class. The number of lineaments and lineament intersections per unit area $(5 \mathrm{~km} \times 5 \mathrm{~km}$ cell size $)$ were recorded and isolineament density and isolineament intersection maps were prepared (figure 4). Topographic maps of 1:250,000 scale were used to demarcate linear drainage channels and their orientation and length were recorded. Rose diagrams and cartesian curves (figures 5 and 6) for lineaments and drainage linears show that NNW-SSE, NW-SE, ENE-WSW and NE-SW linear features are predominant. The E-W drainage linears are quite prominent but are not very conspiuous in the lineament direction detected from Landsat images. Scanlines of Landsat images make an angle of less than $10^{\circ}$ with respect to the $\mathrm{E}-\mathrm{W}$ direction and lineaments were categorized with $10^{\circ}$ class interval. Hence, it is possible that near $\mathrm{E}-\mathrm{W}$ lineaments may have been overlooked due to scanline interference. The 
Table 1. Statistical data for lineament orientation and length in Cannanore district and adjoining areas.

\begin{tabular}{ccccccccc}
\hline $\begin{array}{c}\text { Azimuth } \\
\text { class }\end{array}$ & $\begin{array}{c}\text { Total } \\
\text { No. }\end{array}$ & $\begin{array}{c}\text { Total } \\
\text { length } \\
(\mathrm{km})\end{array}$ & $\begin{array}{c}\text { Number } \\
\%\end{array}$ & $\begin{array}{c}\text { Length } \\
\%\end{array}$ & $\begin{array}{c}\text { Mean } \\
\text { length } \\
(\mathrm{km})\end{array}$ & $\begin{array}{c}\text { Std. } \\
\text { deviation } \\
\text { (length) }\end{array}$ & $\begin{array}{c}\text { Mean } \\
\text { Azimuth }\end{array}$ & $\begin{array}{c}\text { Std } \\
\text { deviation } \\
\text { (azimuth) }\end{array}$ \\
\hline $0-10 \mathrm{NW}$ & 12 & 85 & $3 \cdot 26$ & $3 \cdot 40$ & $7 \cdot 08$ & $3 \cdot 80$ & $5 \cdot 83$ & $2 \cdot 19$ \\
$10-20 \mathrm{NW}$ & 26 & 195 & $7 \cdot 07$ & $7 \cdot 52$ & $7 \cdot 52$ & $4 \cdot 93$ & $17 \cdot 00$ & $2 \cdot 66$ \\
$20-30 \mathrm{NW}$ & 37 & 287 & $10 \cdot 00$ & $11 \cdot 46$ & $7 \cdot 76$ & $4 \cdot 11$ & $24 \cdot 82$ & $3 \cdot 03$ \\
$30-40 \mathrm{NW}$ & 24 & 165 & $6 \cdot 52$ & $6 \cdot 59$ & $6 \cdot 88$ & $3 \cdot 90$ & $36 \cdot 04$ & $2 \cdot 56$ \\
$40-50 \mathrm{NW}$ & 24 & 170 & $6 \cdot 52$ & $6 \cdot 79$ & $7 \cdot 08$ & $3 \cdot 93$ & $45 \cdot 67$ & $2 \cdot 29$ \\
$50-60 \mathrm{NW}$ & 10 & $77 \cdot 5$ & $2 \cdot 72$ & $3 \cdot 10$ & $7 \cdot 75$ & $3 \cdot 94$ & $53 \cdot 50$ & $2 \cdot 69$ \\
$60-70 \mathrm{NW}$ & 5 & $37 \cdot 5$ & $1 \cdot 36$ & $1 \cdot 50$ & $4 \cdot 00$ & $3 \cdot 00$ & $68 \cdot 80$ & $2 \cdot 49$ \\
$70-80 \mathrm{NW}$ & 10 & $52 \cdot 5$ & $2 \cdot 72$ & $2 \cdot 10$ & $5 \cdot 25$ & $2 \cdot 89$ & $75 \cdot 60$ & $2 \cdot 42$ \\
$80-90 \mathrm{NW}$ & 14 & $102 \cdot 5$ & $3 \cdot 80$ & $4 \cdot 09$ & $7 \cdot 32$ & $3 \cdot 47$ & $84 \cdot 93$ & $2 \cdot 28$ \\
$0-10 \mathrm{NE}$ & 6 & 45 & $1 \cdot 60$ & $1 \cdot 80$ & $7 \cdot 50$ & $2 \cdot 84$ & $6 \cdot 33$ & $2 \cdot 43$ \\
$10-20 \mathrm{NE}$ & 9 & 50 & $2 \cdot 44$ & $1 \cdot 20$ & $5 \cdot 56$ & $2 \cdot 83$ & $14 \cdot 63$ & $2 \cdot 74$ \\
$20-30 \mathrm{NE}$ & 14 & 75 & $3 \cdot 80$ & $3 \cdot 00$ & $5 \cdot 55$ & $2 \cdot 65$ & $26 \cdot 29$ & $2 \cdot 46$ \\
$30-40 \mathrm{NE}$ & 23 & $157 \cdot 5$ & $6 \cdot 25$ & $6 \cdot 29$ & $6 \cdot 56$ & $6 \cdot 72$ & $35 \cdot 87$ & $2 \cdot 74$ \\
$40-50 \mathrm{NE}$ & 30 & 165 & $8 \cdot 15$ & $6 \cdot 59$ & $5 \cdot 50$ & $3 \cdot 19$ & $44 \cdot 47$ & $2 \cdot 99$ \\
$50-60 \mathrm{NE}$ & 36 & $242 \cdot 5$ & $9 \cdot 78$ & $9 \cdot 69$ & $6 \cdot 74$ & $5 \cdot 10$ & $55 \cdot 61$ & $2 \cdot 76$ \\
$60-70 \mathrm{NE}$ & 40 & $267 \cdot 5$ & $10 \cdot 87$ & $10 \cdot 69$ & $6 \cdot 39$ & $6 \cdot 05$ & $66 \cdot 50$ & $2 \cdot 73$ \\
$70-80 \mathrm{NE}$ & 31 & 223 & $8 \cdot 42$ & $8 \cdot 91$ & $7 \cdot 19$ & $5 \cdot 18$ & $74 \cdot 19$ & $2 \cdot 53$ \\
$80-90 \mathrm{NE}$ & 17 & 106 & $4 \cdot 62$ & $4 \cdot 23$ & $7 \cdot 09$ & $4 \cdot 20$ & $84 \cdot 82$ & $2 \cdot 26$ \\
\hline
\end{tabular}

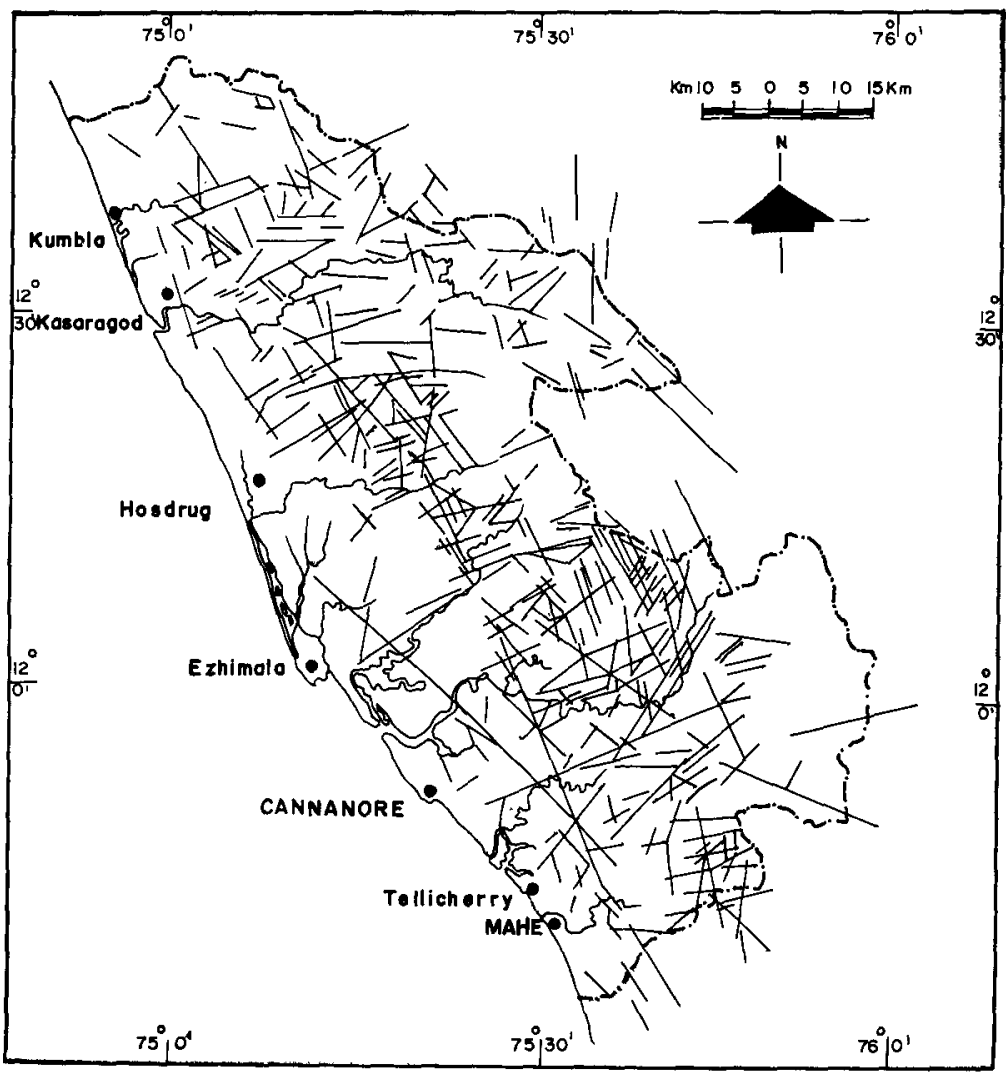

Figure 3. Lineament map of Cannanore district and adjoining area. 

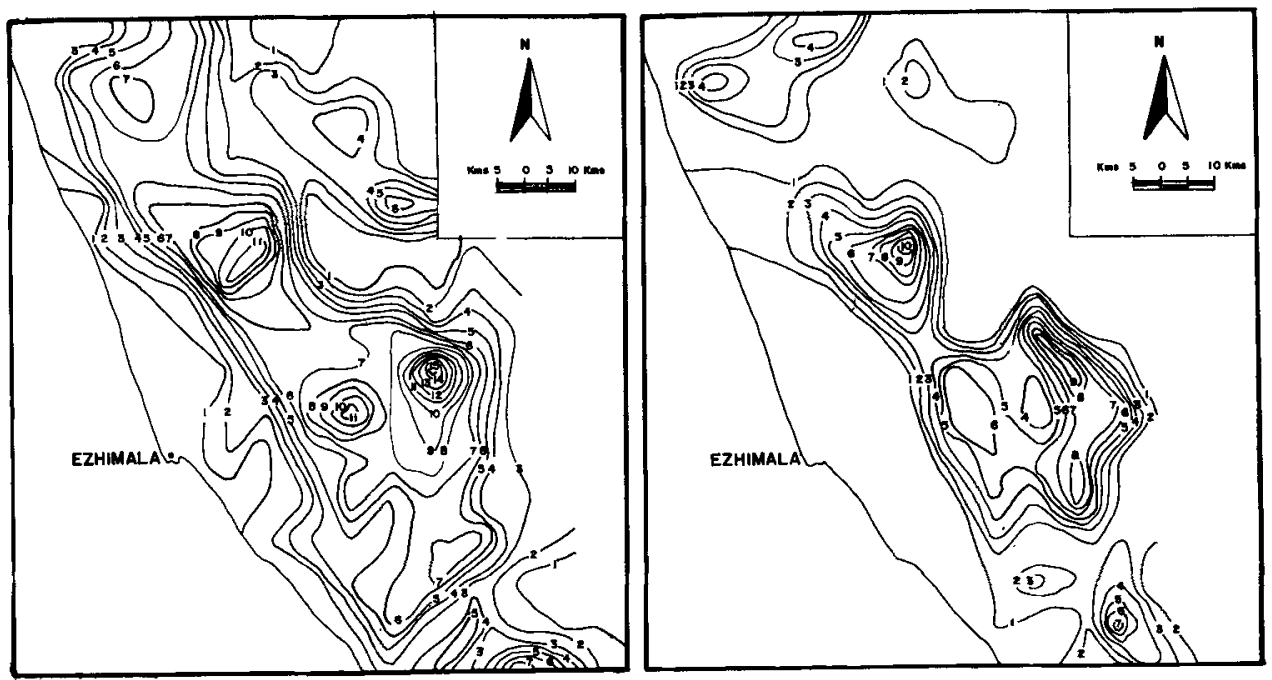

Figure 4. Isolineament density and isolinement intersection maps for Cannanore region.

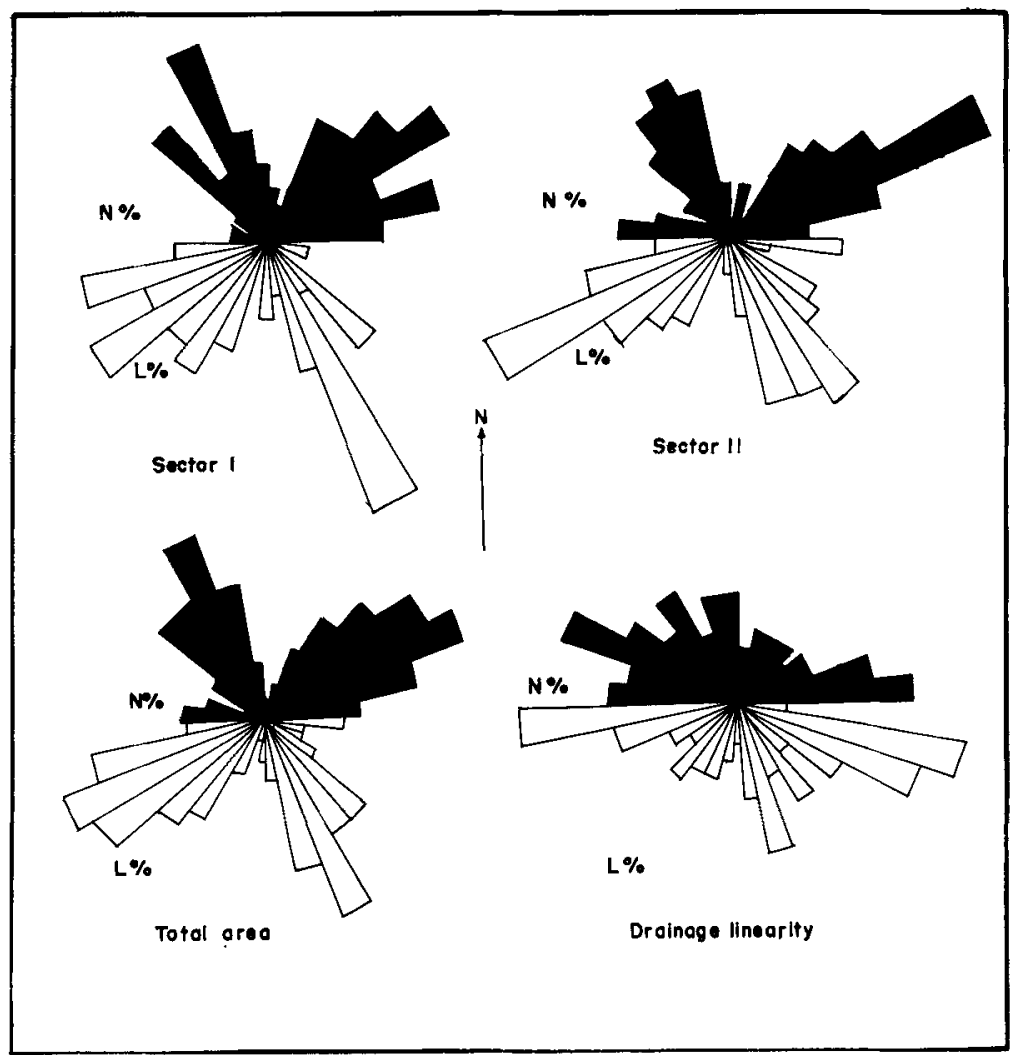

Figure 5. Rose diagram for linear features in Cannanore region $(\mathrm{N} \%=$ number percent; $\mathrm{L} \%=$ length percent) 


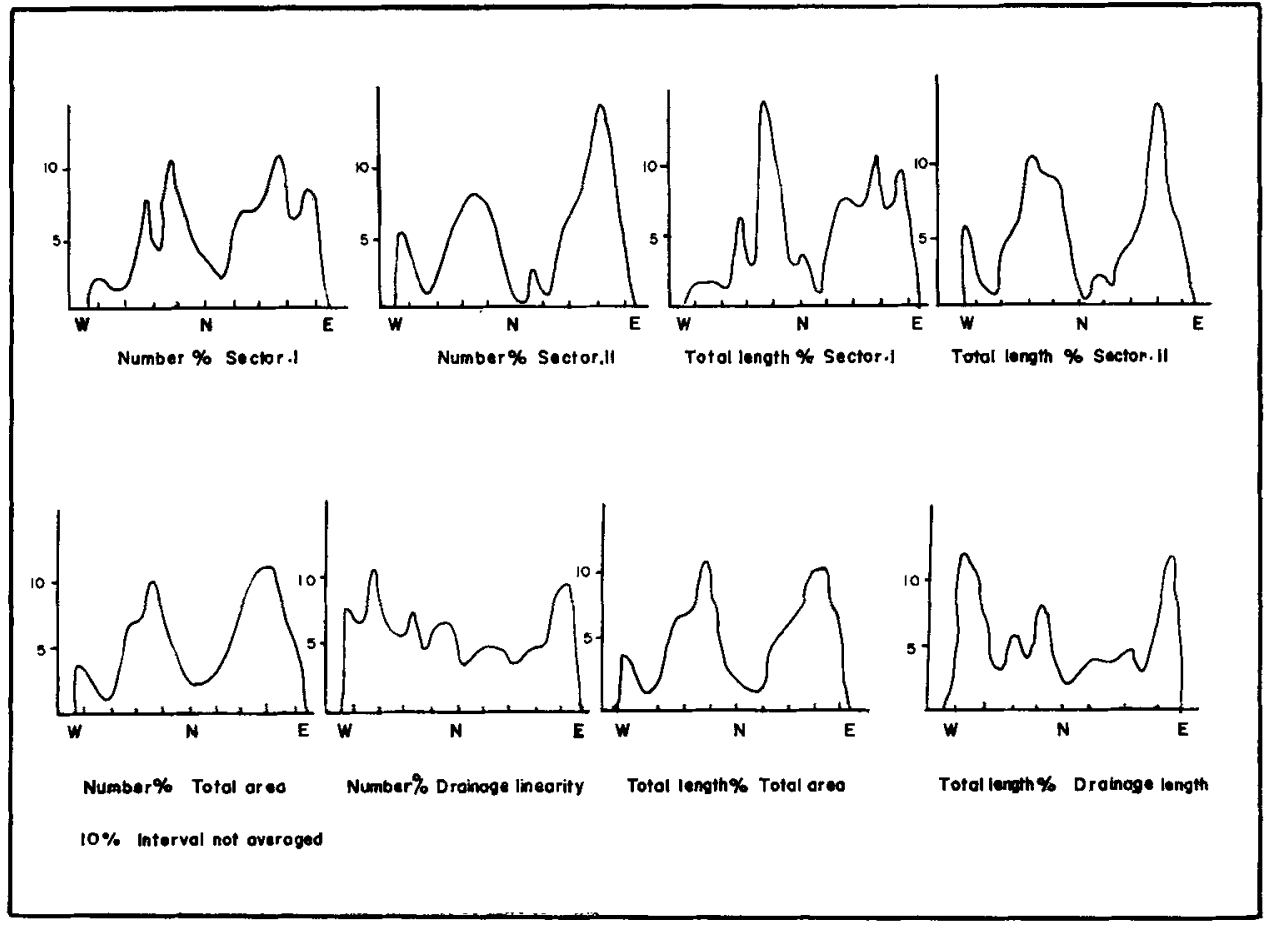

Figure 6. Cartesian curves for linear features in Cannanore region.

E-W trends in some cases may not be related to structural features since these coincide with the general slope direction. However, the relationship between stream order and stream length and bifurcation ratio values for drainage basins (unpublished data of the authors) suggest that the drainage development in the area is structurally controlled.

The lineament density isolines indicate more continuous zones of density anomalies and intersection isolines correlate more with the difference in topography. The lineament density and intersection density maps (figure 4) show two prominent anomalies in the area NE (sector I) and SE (sector II) of Elimala. In sector I the NNW-SSE lineaments are prominent $(15 \%)$ whereas in sector II the ENE-WSW lineaments are predominant $(20 \%)$. The NW-SE and NE-SW lineaments are more or less evenly distributed. Distribution of lineaments in major azimuth classes is shown in figure 7.

\section{Discussion and Conclusions}

The NNW-SSE, NW-SE, ENE-WSW and NE-SW trending lineaments are predominant in the study area. Dyke swarms in the area occur mainly along the NNW-SSE and ENE-WSW trends with minor fluctuations to the NE-SW and NW-SE directions. Dykes can be, treated as natural fractures dilated by a combination of crustal extension and magma pressure (Anderson 1972). In case of 
pure dilation, dykes tend to get emplaced along the principal stress plane and the least compressive stress acts normal to the dyke (Pollard 1985). Rouchet (1981) indicated that, in folded structures created by compression, the open fractures extend parallel to the maximum stress axis. These fractures would thus be perpendicular to the fold axis. Hence, the NNW-SSE fractures in the Cannanore region are suggested to represent tensional fractures and could have developed due to near $\mathrm{N}-\mathrm{S}$ compression. The $\mathrm{N}-\mathrm{S}$ compression may be related to the early deformational episode which resulted in the formation of folded structures with E-W axial trends. The NW-SE to NNW-SSE enechelon fractures and/or dykes (Nair et al 1975) also suggest a near N-S compression (Badgely 1965; Wilson 1985).

Similarly the ENE-WSW lineaments can be related to a later deformation event that have produced folds with NW-SE to NNW-SSE axial plane. The ENE-WSW

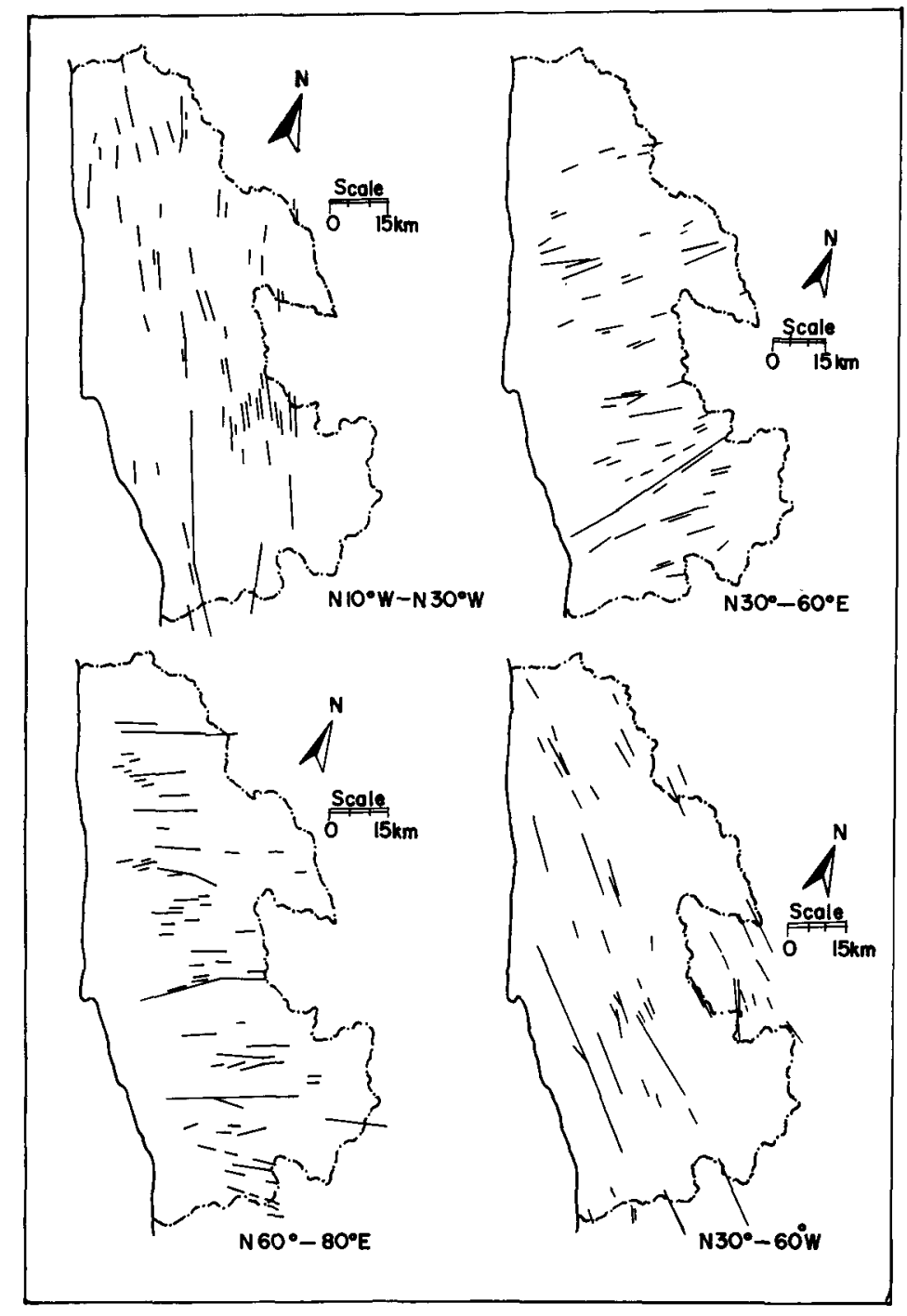

Figure 7. Distribution of lineaments in different azimuth classes. 
dyke swarms may also suggest a $\mathrm{N}-\mathrm{S}$ extension but in the absence of any large scale rifting (Drury et al 1984) it seems more probable that the fractures resulted due to near $\mathrm{E}-\mathrm{W}$ compression. The same deformational event might have resulted in the generation of NW-SE lineaments parallel to the axial plane. The NE-SW lineaments relate to a different tectonic event and are considered to have developed during the cross folding of earlier folds along the NE-SW to NNE-SSW axis (Nair et al 1975). The above discussion reveals that NNW-SSE and ENE-WSW lineaments are related to Precambrian deformational event contrary to the present notion that they are responses to the rifting of the western continental margin of India about $110 \mathrm{~m} . \mathrm{y}$. ago.

The occurrence of basic dyke enclaves within the $760 \pm 70 \mathrm{~m}$.y. granite and the Proterozoic ages of a few dykes (Radhakrishna et al 1985, 1986) for which these fractures acted as conduits further supports the contention that the fracturing was initiated during early Proterozoic times. Similarly, Precambrian origin of the ENE-WSW fractures is supported by the occurrence of older igneous bodies along these lineaments and the suggested genetic correlation of the ENE-WSW basic dykes to those of the Cuddapah region (Drury 1984).

In summary, the Precambrian crustal fractures have had a profound influence on the tectonic evolution of the Cannanore region of Kerala. These lineaments have served as conduits for the emplacement of igneous bodies at different stages between the Proterozoic and the Mesozoic times. These fractures are suggested to have been periodically reactivated during which younger igneous bodies were emplaced along them, the basic dyke intrusions of Mesozoic being one of the phases.

\section{Acknowledgements}

The authors thank Dr P K Raha for useful comments on the manuscript and Dr S K Ghosh, Dr T Radhakrishna and Mr G Sankar for encouragement and assistance.

\section{References}

Anderson E M 1972 The dynamics of faulting and dyke formation with applications to Britain (New York: Hafner Pub. Co.) p. 206

Badgley P C 1965 Structural and Tectonic Principles (New York: Harper and Row) 521

Drury S A and Holt R W 1980 Tectonophysics 651

Drury S A, Harris N B W, Holt R W and Reeves-Smith G J 1984 J. Geol. 923

Drury S A 1984 J. Geol. Soc. India 25437

Eremenko N A 1968 Geol. Soc. India Mem. 2371

Furnes H, Hertogen J, Mitchell J G, Austaheim H and Sinha Roy S 1983 Neues Jb. Miner. Abh. 14682 Katz M 1982 Mineral exploration techniques in tropical rain forest area (eds) D J C Laming and A K Gibbs $A G I D$-Report 7157

Murthy Y G K, Tampi P K and Nair M M 1976 Abstract, geology and geomorphology of Kerala, Trivandrum

Nair M M, Vidhyadharan K T, Pawar S D, Sukumaran P V and Murthy Y G K 1975 Indian Minerol. 16 89

Nair M M, Pawar S D Vidhyadharan K T and Senthiappan M 1980 G. S. I. Spec. Pub. No. 59 
Nair P K R and Nair E V R 1980 G. S. I. Spec. Pub. No. 513

Pollard D D 1985 Abstract, International conference on mafic dyke swarms, Toronto 136

Rao P S 1978 G. S. I. Miscelleneous Pub. No. 34 Part III 51

Radhakrishna T. Mitchell J G and Venkatesh R 1985 Abstract, international conference on mafic dyke swarms 141

Radhakrishna T. Rao G V S P, Mitchell J G, Venkatesh A S 1986 J. Geol. Soc. India 27245

Rouchet du J 1981 AAPG Bull. 6574

Sinha Roy S and Furnes H 1981 Neues Jb. Miner. Abh. 14249

Vardarajan K and Nair M K $1978 \mathrm{~J}$. Geol. Soc. India 19217

Wilson B C 1985 Abstract, Int. con. on mafic dyke swarms, Toronto 186 